\title{
Katarzyna DUDA
}

Uniwersytet Jagielloński

k.duda@op.pl

\section{NARODY KRAJU RAD}

\section{WSPÓŁISTNIENIE I ZATOMIZOWANIE KULTUR (TWÓRCZOŚĆ LUDMIŁY ULICKIEJ)}

ABSTRACT The nations of Soviet Union. The coexistence and distraction of cultures (the literary output of Ludmila Ulitskaya)

After the October Revolution different nations were forced to live together on the area of totalitarian Soviet Union. Their history got worse after the Second World War when Soviet soldiers and especially Stalyn were considered as winners and in this way they cold "colonise" new countries. Their citizens wanted to regain freedom in the 60's and 70's od twentieth century. They were called dissidents. One of the most famous modern Russian writers who presents these subject matters is Ludmila Ulitskaya - the representative of new realism whose books have been translated into 25 languages. In her novels and short stories she concentrates mainly on the silmilarities and differences between The Russians and other nations being under communistic control. Ulitskaya shows that some of them wanted to keep their identity by looking after their own tradition, religion, customs. The novelist tries to prove that it is possible to coexist with each other if you respect different habits and culture and if you desire to communicate with others using constructive dialogue.

Słowa kluczowe: nowy realizm, totalitaryzm, narody, kultura

Key-words: new realism, totalitarianism, nations, culture 
W

czasach współczesnych w Rosji pisarz przestał pełnić funkcję proroka i nauczyciela, któremu przypadło w udziale wypełnienie szczególnej misji związanej z głoszeniem prawdy w kraju, w którym panowało kłamstwo, z prognozowaniem trendów przyszłości po upadku ZSRR. Jednakże literaturocentryzm to nadal ważna tendencja odróżniająca literaturę rosyjską od literatur innych krajów. W Federacji Rosyjskiej literatura, na razie, nie została wyparta przez teksty nacechowane gospodarczo, ekonomicznie, a więc takie, które w ponowoczesnym świecie uznaje się za pożyteczne, bo zaspokajające potrzeby materialne i gwarantujące, wątpliwy niejednokrotnie, sukces w zdobyciu ważnego miejsca na rynku pracy. Biznes, finanse, bankowość nie zdołały, póki co, wyrugować wartości duchowych, osiągnięć szeroko pojmowanej kultury i sztuki. Przed literaturą współczesną nadal więc stoi ważne zadanie: utrwalania znaczeń i symboli, które świadczyć będą z jednej strony o tożsamości narodów zamieszkujących Federację Rosyjską, z drugiej - o istnieniu pewnych cech wspólnych dla przedstawicieli gatunku homo sapiens. Nie potrzeba wojen, wybuchów jądrowych, deszczu meteorytów, aby zniszczyć naród; bez duchowego dziedzictwa, bez tradycji narody wyginą same - zdają się podpowiadać pisarze rosyjscy. Jedną z autorek podzielających to zdanie jest, uhonorowana wieloma prestiżowymi międzynarodowymi nagrodami literackimi, przedstawicielka nowego realizmu - Ludmiła Ulicka. Przypomnijmy w tym miejscu, iż nowy realizm poszukuje takich sposobów wypowiedzi, oglądu i interpretowania rzeczywistości, które są pozbawione programowego dydaktyzmu, pozwalają rezygnować z formułowania ideałów i modeli zachowań, orientują się na pokazywanie, a wydawanie opinii pozostawiają czytelnikowi ${ }^{1}$. Nowi realiści dokonują opisu i analizy otaczającej ich rzeczywistości poprzez pryzmat prywatności, z punktu widzenia jednostki. Historia i polityka, stale obecne w utworach nowych realistów, przefiltrowane zostają przez przeżycia indywidualne, zyskując przez to większą psychologiczną wiarygodność i odcinając się od fałszywego, socrealistycznego kolektywu na rzecz doznań jednostkowych ${ }^{2}$. Nowi realiści odrzucają nie tylko ideologiczne racje realizmu socjalistycznego, ale również jego formalne stereotypy. Ta literatura świadomie orientuje się na burzenie mitów, na pokazywanie tego, czego socrealizm unikał: ciasnoty i zaduchu „komunałek”, przyjaźni bądź wrogości narodów zamieszkujących ZSRR, indywidualności w rozmaitych jej przejawach, obojętności otoczenia, nieuleczalnych chorób, obłąkania, poczucia zabrnięcia w ślepy zaułek w ludzkiej egzystencji, alkoholizmu i jego skutków fizycznych i moralnych ${ }^{3}$. Proza nowego realizmu często podkreśla absurdalne aspekty rzeczywistości, żyje ze świadomością tego, że, jak piszą Piotr Wajl i Aleksander Genis: nasz wiek to wiek straconych ztudzeń [...]. Nasz wiek [mowa o wieku XX - K.D.] wykorzystat wiare w ideaty do końca. On je po prostu zrealizowat. Po 1917 roku ideatów nie stato - wszystkie zostaty wcielone w życie. Rezultaty zrealizowanych uto-

1 J. Sałajczykowa, Dziesięciolecie przemian. Proza rosyjska lat 1985-1995, Gdańsk 1998, s. 13.

2 K. Duda, Wspótczesna literatura rosyjska wobec historii (nowy realizm Ludmity Unickiej), [w:] Kultura ipolityka, red. L. Suchanek, Kraków 2008, s. 48, Prace Komisji Kultury Stowian PAU, 8.

3 J. Sałajczykowa, Dziesięciolecie przemian..., s. 14. 
pii okazaty się przerażajace nie tylko dla ich wykonawców [...]. Totalny sceptycyzm - oto cena spotecznych eksperymentów $w^{4}$

Sceptycyzm, a obok niego ironia i parodiowanie - to także cechy prozy nowego realizmu. A jednocześnie obok tego znajdziemy refleksy liryzmu. Warta odnotowania jest tu również skłonność do korzystania ze starej mitologii, jak i próby tworzenia nowej. W nurcie noworealistycznym spotykamy się zarówno z różnorodnością gatunkową (np. Ulicka jest autorką powieści, opowiadań, opowieści, bajek), jak i tematyczno-problemową. Znów niezmiernie aktualne stają się motywy inteligenckich rozterek, rozdwojonej świadomości, trudności wynikających z rozstawania się z „bohaterską przeszłością”, szukania swojego miejsca w nowej rzeczywistościs. Wydarzenia fabularne są z reguły sytuowane (jak się to dzieje właśnie u Ulickiej) w konkretnej rzeczywistości historycznej, ukazywane z dbałością o szczegóły. Utwory te, najogólniej rzecz ujmując, odzwierciedlają różne aspekty kryzysu tożsamości, jakiego doświadcza postsowieckie społeczeństwo, ukazują panujące typowe nastroje i emocje - od wzmożonej agresywności po rezygnację i beznadzieję. Nowi realiści orientują się na zrozumienie dylematów współczesnego człowieka, na współczucie mu, zwłaszcza jego poczuciu samotności. Ukazują także chaos i różne absurdy życia, egzystencjalny strach towarzyszący człowiekowi na każdym niemal kroku.

Książki Ulickiej przetłumaczone zostały na wiele języków obcych, w tym również, dzięki wydawnictwu Philip Wilson, na polski. Polscy czytelnicy z entuzjazmem odnieśli się do, niełatwych w odbiorze, powieści: Przypadek Doktora Kukockiego, Szczerze oddany Szurik, Sonieczka, Daniel Stein - ttumacz czy też, najbardziej nas tu interesującej, Medea i jej dzieci.

Ludmiła Ulicka urodziła się w rodzinie inteligenckiej (ojciec był inżynierem, matka - biochemikiem) w 1943 r. w Dawliekanowie - baszkirskim mieście, dokąa jej rodzina ewakuowana została z Moskwy w czasie II wojny światowej. Pochodzi z domu, w którym żywe były tradycje pisarskie: jej dziadek ze strony ojca był autorem dwóch książek - jednej z teorii muzyki, druga to pionierska na gruncie rosyjskim praca z dziedziny demografii. Ten przodek pisarki siedemnaście lat spędził w radzieckich łagrach, po rehabilitacji i powrocie do domu, na skutek obozowej traumy i odniesionych tam chorób - zmarł. Podobny los spotkał drugiego dziadka ${ }^{6}$, dlatego też rodzina Ulickiej nigdy nie miała wątpliwości co do zbrodniczego charakteru komunizmu. Prababka przyszłej pisarki tworzyła wiersze, a jej syn - Michaił Pietrowicz Galperni - był literatem, reżyserem i kulturoznawcą. Wyposażona w takie zaplecze Ulicka rozpoczęła swój związek z literaturą właśnie od poezji. Jeden z jej wierszy opublikowany został w podziemnym żydowskim czasopiśmie „Tarbut”. Zrażona ostrą krytyką swej przyjaciółki, poetki Natalii Gorbaniewskiej, Ulicka zarzuciła paranie się mową wiązaną. Pasja ta jednak przetrwała w niej długo, skoro kilka wierszy włożyła w usta bohaterki Medei i jej dzieci. Gwoli sprawiedliwości należy dodać, iż Gorbaniewska była jedną z pierwszych

4 П. Вайль, А. Генис, Современнал русскал проза, Ann Arbor 1982, s. 57-58. Wszystkie tłumaczenia z tekstów obcojęzycznych, jeśli nie podano inaczej, własne - K.D.

5 J. Sałajczykowa, Dziesięciolecie przemian..., s. 167.

6 Ludmita Ulicka, s. 1, [online] http://buker.obninsk.ru/h_ulitskaya, 6 III 2012. 
recenzentek prozatorskich utworów Ulickiej i chętnie drukowała je na łamach emigraсуjnego pisma „Russkaja Mysl” („Русская мысль”).

Ulicka ukończyła biologię (ze specjalnością - genetyka) na uniwersytecie w Moskwie. Jeszcze przed rozpoczęciem studiów pracowała na uniwersytecie jako laborantka w Instytucie Pediatrii. Po uzyskaniu dyplomu była stażystką w Instytucie Genetyki Ogólnej. Została jednak stamtąd zwolniona za wypowiedzianą głośno uwagę o nepotyzmie i zaniedbaniach w radzieckich laboratoriach. Dziewięć lat była bezrobotna. W tym czasie urodziła dwóch synów (obecnie jeden z nich jest inżynierem, drugi muzykiem jazzowym). W latach 1979-1982 była zatrudniona jako kierownik literacki w muzycznym Kameralnym Teatrze Żydowskim.

Rok 1982 stanowi w życiu Ulickiej swego rodzaju cezurę, w tym bowiem czasie podjęła decyzję, że poświęci się całkowicie rzemiosłu literackiemu. W tym też okresie rozpoczęła naukę pisania scenariuszy do filmów animowanych. Wiele z nich zostało zrealizowanych w Sojuzmultfilmie (Союзмультфиль). W tym samym czasie pisała też dramaty, które następnie zaadaptowane zostały dla potrzeb kinematografii. Na bazie jej utworów powstały np. filmy Siostrzyczki Liberti (reż. Władimir Grammatikow, studio Gorkiego) oraz Kobieta dla wszystkich (reż. Anatolij Mateszko, studio Dowżenki). Równocześnie w wydawnictwie Małysz (Малыш) ukazały się jej pierwsze książki dla dzieci: Sto guzików i Trudne stowo „nie”. Wtedy zajęła się także tłumaczeniem wierszy z języka mongolskiego.

Pod koniec lat 80. pojawity się pierwsze publikacje jej opowiadań w czasopismach. Utwory nowej autorki najpierw wydrukowało pismo „Krestianka” („Крестьянка”), a potem „Ogoniok” („Огонёк”) i „Nowyj Mir” („Новый мир”). W 1994 r. wyszedł w języku rosyjskim pierwszy zbiór opowiadań Ulickiej Biedni krewniacy. Tak się złożyło, że wspomniana książka pod tym samym tytułem (choć z wyłączeniem utworu Sonieczka) wydana została w języku francuskim w wydawnictwie Gallimar. Zarówno wydanie rosyjskie, jak i francuskie pozostały niemal niezauważone. Dopiero utwór Sonieczka okazał się tą książką, którą wysoko ocenili krytycy: uhonorowano ją w 1996 r. we Francji prestiżową nagrodą literacką dla pisarzy zagranicznych - Medici, jak również włoską Nagrodą im. Giuseppe Adserbiego.

A zatem, mimo iż pisarski debiut Ulickiej był późny, to jej kariera literacka okazała się niezwykle owocna, a dorobek - imponujący. W ciągu dziesięciu lat jej książki przetłumaczono na dwadzieścia pięć języków, są one szeroko znane i cenione na całym świecie. Często podkreśla się, iż Ulicka sprawiła, że czytelnik z Zachodu znów zaczął mówić o odradzaniu się duchowości wielkiej prozy rosyjskiej.

Jest jedyną pisarką, która trafiła do złotej dziesiątki twórców zestawionej przez „Magazine Litteraire” (w numerze 3 z 2005 r. poświęconym literaturze rosyjskiej). 6 grudnia 2001 r. Ulicka otrzymała Nagrodę Bookera za powieść Przypadek doktora Kukockiego, współzawodnicząc z takimi rosyjskimi pisarzami doby współczesnej, jak Tatiana Tołstoj, Aleksiej Czudakow, Alan Czerczesow i Anatolij Najman7. Wyróżniona książka została sfilmowana przez Jurija Grymowa i w takiej formie również odniosła sukces.

Аюдмила Улицкал - лауреат премии „Букер - 2001”, s. 1, [online] http://www.ror.ru/culture/cultarch197_rus!html, 9 VII 2012. 
Lejtmotywem przewijającym się przez wszystkie utwory Ulickiej jest, narzucona ludziom często metodami siłowymi, wielokulturowość, próba odpowiedzi na pytanie, jak zachować tożsamość w tyglu narodowościowym, jak żyć zgodnie nie tylko obok siebie, ale i ze sobą. Autorka, bez wykorzystywania nadmiernego dydaktyzmu, zdaje się podpowiadać, że wspólistnienie takie, nawet w obrębie Kraju Rad, było możliwe, jeśli wykorzystywało się możliwości dialogu międzykulturowego, strzegło się zasady „,jedności w różnorodności”, postępując zgodnie z ideologią tolerancjonizmu ${ }^{8}$. W praktyce prowadzi to do przekonania, że swoistość każdej grupy etnicznej musi być w pełni respektowana i akceptowana. Dlatego m.in. narratorka powieści Medea i jej dzieci będzie mogła ją zakończyć optymistycznymi słowami: Cieszę się, że jestem dzięki mężowi spokrewniona $z$ ta rodzina [z rodziną Medei - K.D.] i że moje dzieci maja troche greckiej krwi, krwi Medei. Jej „późne wnuki” wciąż zbieraja się każdego lata w Osadzie - Rosjanie, Litwini, Gruzini, Koreańczycy... ${ }^{9}$. Optymizm ten jednak ujawnił się z perspektywy końca XX w. (książka została napisana pod koniec 1996 r.), natomiast fabuła powieści obejmująca lata 1900-1977 wskazuje na spustoszenia, jakich władza radziecka dokonała w stosunkach interpersonalnych, w dziedzinie, którą dzisiaj określamy mianem „kwestii narodowościowej”, pamiętając iż stała się ona jednym z najważniejszych punktów zapalnych, które doprowadziły do upadku ZSRR. W ten sposób beletrystyka stapia się u Ulickiej z rozważaniami o kulturze i z zagadnieniami politycznymi.

Polityka pojawia się na kartach powieści wraz z rozważaniami o zrywie październikowym 1917 r. Rewolucja przyrzekła, że zlikwiduje kwestię narodowościową w dawnym imperium rosyjskim, które stało się państwem socjalistycznym. Stalin obwieścił o jej ostatecznym rozwiązaniu ${ }^{10}$. Do 1922 r. rządowi komunistycznemu udało się przede wszystkim zbrojnie - przywrócić kontrolę nad większą częścią terytorium byłego Cesarstwa Rosyjskiego i odtworzyć je pod nową nazwą: Związek Socjalistycznych Republik Radzieckich. Totalitarnego charakteru komunizmu nie da się jednak przedstawić jako przedłużenia tradycyjnego rosyjskiego autorytaryzmu czy wschodniego despotyzmu; podobnie jak nie można kolektywistycznego charakteru radzieckiego społeczeństwa interpretować jako kontynuacji tradycyjnych rosyjskich stosunków społecznych, opartych na wspólnocie i poddaństwie. Trudno jest znaleźć jakieś konkretne instytucjonalne lub intelektualne elementy przejścia od starego rosyjskiego porządku do polityki prowadzonej przez bolszewików po roku $1917^{11}$. Deportacje etniczne, niepasujące do ogólnej radzieckiej polityki wspierania tożsamości narodowej i zaplecza terytorialnego o różnym składzie etnicznym, obejmowały członków narodowości „przygranicznych”, takich jak Finowie czy Koreańczycy, którzy mogli się poczuwać do lojalności wobec państw innych niż Związek Radziecki. NKWD wywoził

W. Daszkiewicz, Wielokulturowość a ideologia multikulturalizmu, „Cywilizacja” 2010, nr 33, s. 197.

L. Ulicka, Medea i jej dzieci, przeł. R. Bartosik, Warszawa 2004, s. 340. Wszystkie cytaty z tego wydania.

10 M. Heller, A. Niekricz, Utopia u wtadzy. Historia Zwiazku Sowieckiego, t. 2, przeł. A. Mietkowski, Wrocław 1989, s. 340.

11 M. Malia, Sowiecka tragedia. Historia komunistycznego imperium rosyjskiego 1917-1991, przeł. M. Hułas, E. Wyzner, Warszawa 1994, s. 168. 
ich tak samo jak kilka lat wcześniej kułaków i zmuszał do osiedlenia w centrum kraju. Wywózki te, jak zauważa Sheila Fitzpatrick, były zapowiedzią lepiej znanych przesiedleń Niemców nadwołżańskich i Czeczenów w latach 40. XX w. ${ }^{12}$ Choć nieupubliczniane i prowadzone na stosunkowo małą skalę, deportacje etniczne pozostawiły na tyle mocny ślad w świadomości społecznej, przynajmniej w obwodzie leningradzkim, że np. pewien mężczyzna o fińskim nazwisku odmówił odpowiedzi rachmistrzowi spisowemu w 1939 r. Warto w tym miejscu przypomnieć, że bolszewicy dążyli do oderwania pojęcia narodu od pojęcia państwa. Naród był dla nich zbiorowością etniczną, niemalże plemienną, a nie polityczną wspólnotą obywateli ${ }^{13}$. Jednakże, jak twierdzi np. Włodzimierz Marciniak, narody i kultury narodowe nie stanowiły dla bolszewików bezpośredniego zagrożenia. Narody traktowali oni bowiem jako niższą formę rzeczywistości społecznej, użyteczną z punktu widzenia realizacji utopii komunistycznej ${ }^{14}$. $\mathrm{Z}$ tego też względu ideologicznym imperatywem imperium było osiągnięcie jedności wszystkich narodów. Komuniści budowali piramidę narodów, na której szczycie stali ludzie radzieccy, niezależnie od pochodzenia wychowani w duchu sowieckiej kultury. Niżej znajdowali się przedstawiciele rdzennych narodów republik związkowych, a najniżej członkowie innych narodów, pozbawionych swoich terytorialnych enklaw, którzy powinni się byli z realiami radzieckimi zasymilować.

Medea, która widziata cata krymska tragedię i pamiętata gtód, chtód i baraki dla chorych na tyfus, nigdy sama nie przeżta przesiedlenia, co byto $w$ Kraju Rad na porzadku dziennym, $i$ tylko z opowiadan wiedziata o bydlęcych wagonach $i$ kolejkach na stacjach po goraca wodę (s. 228) - tymi słowami wprowadza Ulicka sprawę narodów przesiedlonych w czasie II wojny światowej i po niej. System podjął wówczas nowe zadania represyjne. Jedną z nich była zmiana etnicznej mapy Związku Radzieckiego poprzez deportacje całych narodowości, rzekomo w interesie bezpieczeństwa. Pierwszą w kolejności grupą byli Niemcy nadwołżańscy. Chociaż przebywali w Rosji od prawie dwustu lat i przez cały czas pozostawali lojalni, w 1941 r. deportowano ich do Azji Środkowej. W roku 1944, po niemieckim odwrocie z północnego Kaukazu i Krymu, Czeczenów i Inguszów, Tatarów krymskich i inne małe narodowości również zesłano do Azji Środkowej ${ }^{15}$. Pod koniec lat $70 . \mathrm{XX}$ w. najważniejsze postacie kultury z nierosyjskich narodowości były systematycznie wydalane z Kaukazu, Ukrainy i krajów bałtyckich.

Klamrą kompozycyjną książki Ulickiej są, wyróżnione kursywą, a więc podkreślające wagę wydarzeń, sekwencje dotyczące właśnie kwestii narodowościowej, a dokładnie Tatarów krymskich. Medea (w liście do krewnej) podaje nawet dokładną datę, która utrwaliła się w jej świadomości do końca życia. Było to jedenastego kwietnia tysiąc dziewięćset siedemdziesiątego szóstego roku (s. 12), kiedy do krymskiego domu protagonistki

12 S. Fitzpatrick, Życie codzienne pod rzadami Stalina. Rosja radziecka w latach trzydziestych XX wieku, przeł. J. Gilewicz, Kraków 2012, s. 180-181, Historiai.

13 А. Вишневский, Единая и неделимая, „Полис” 1994, nr 2, s. 32.

14 W. Marciniak, Rozgrabione imperium. Upadek Zwiazku Sowieckiego i powstanie Federacji Rosyjskiej, Kraków 2004, s. 27-28, Arkana Historii.

15 M. Malia, Sowiecka tragedia..., s. 326. 
przybył Rawil, który wyznał, że walczy o powrót Tatarów na Krym, że oni od dawna podejmują różne oficjalne i nieoficjalne kroki w tym kierunku. Chwytat każde moje stowo o starym tatarskim Krymie, nawet notowat i nagrywat na magnetofon, żeby przekazać Tatarom mieszkajacym w Uzbekistanie i Kazachstanie [...]. Opowiedziatam mu, jak wysiedlali okolicznych Tatarów, dając im dwie godziny na spakowanie się... (s. 13). Przypomnijmy, że Tatarzy krymscy byli jednym z ośmiu narodów zamieszkujących Związek Radziecki, które w czasie II wojny światowej zostały w całości deportowane z miejsca stałego zamieszka$\mathrm{nia}^{16}$. W latach 1944-1948 tatarskie, tradycyjne nazwy geograficzne zostały zmienione na rosyjskie (stare nazwy zachowało tylko kilka dużych miast). We wrześniu 1948 r. na sesji Akademii Nauk ZSRR zainicjowano rewizję historii Krymu ${ }^{17}$.

Wydany podczas chruszczowowskiej „odwilży” dekret Prezydium Rady Najwyższej ZSRR o zniesieniu ograniczeń związanych z przesiedleniem specjalnym uwolnił Tatarów krymskich od rygoru przesiedleńczego i nadzoru administracyjnego. Zniesienie ograniczeń nie pociągnęło jednak za sobą zwrotu mienia skonfiskowanego podczas wysiedlenia ani zezwolenia na powrót do dawnych miejsc zamieszkania (tu należy podkreślić, że Medea mieszka w domu dziadka Rawila). Sytuacja Tatarów krymskich stała się od roku 1967 częstym tematem listów otwartych moskiewskich obrońców praw człowieka. Ruch Tatarów krymskich jako pierwszy ruch narodowy znalazł się w polu zainteresowania dysydentów, gdyż, w odróżnieniu na przykład od ruchu litewskiego czy ormiańskiego, łatwo było przedstawić go w kategoriach prawa w ogóle, a zwłaszcza praw człowieka. Poza tym metody walki Tatarów krymskich były od samego początku bliskie stołecznym dysydentom, podczas gdy w innych ruchach narodowych dominowały metody walki podziemnej ${ }^{18}$.

Ale ja tu jeszcze kiedyś wrócę, czasy się zmienia, jestem tego pewny (s. 15) - to zapewnienie Rawila wprowadza zagadnienie zaktywizowania się tatarskiego ruchu dysydenckiego. Znacznie zwiększyło się zainteresowanie Tatarów krymskich własną historią i kulturą, co świadczyło o wzroście świadomości narodowej ${ }^{19}$. Dociekania historyczne lat 60 . i 70. XX w. były dla młodych Tatarów krymskich równoznaczne z poszukiwaniem własnej tożsamości, zaś dla starszych - próbą odrzucenia ciążącego na narodzie piętna zdrajcy i wroga. Ruch Tatarów krymskich stawał się z każdym rokiem coraz bardziej zorganizowany i aktywny. Ważnym przedsięwzięciem było nawiązanie kontaktu z ruchem obrony praw człowieka w ZSRR („kwestią tatarską” zajęli się tu przede wszystkim Aleksiej Kostierin i Piotr Grigorienko). Walczący o swoje prawa Tatarzy krymscy poddawani byli represjom, uznano ich za elementy nastawione nacjonalistycznie: w ten sposób automatycznie trafili do kategorii nieprawomyślnych.

16 Stownik dysydentów. Czotowe postacie ruchów opozycyjnych w krajach komunistycznych w latach 1956-1989, t. 2: Armenia, Azerbejdżan, Biatoruś, Estonia, Gruzja, Litwa, Eotwa, Motdawia, Rosja, Ukraina i Tatarzy Krymscy, Warszawa 2007, s. 718.

17 А. Алексеева, История инакомыслия в СССР. Новейиий период, Vilnius-Moskwa 1992, s. 334.

18 Stownik dysydentów..., s. 15.

19 Na ten temat zob.: K. Duda, Andriej Amalrik - rosyjski dysydent, Kraków 2010, Literatura Rosyjska Emigracja - Tamizdat-Samizdat, 15. 
Dobra wola, uczciwość oraz sprawiedliwość kazała Medei Synopli przekazać (na mocy swego testamentu) dom rodzinie Rawila: Gieorgij pokazat Rawilowi testament $z$ kuferka. Musiato jednak minać kolejnych pare lat, zanim Rawil otrzymat ten dom. Btaha sprawa zmiany wtaściciela ciagnęta się $w$ sądzie przez dwa lata i skończyta się pomyślnie wytacznie dzięki uporowi Georgija, który doszedt aż do wtadz republikańskich, żeby uznano testament Medei (s. 338). Gwoli obiektywizmu historycznego należy dodać, że 14 listopada 1989 r. Rada Najwyższa ZSRR przyjęła deklarację O uznaniu aktów represji wobec narodów przymusowo przesiedlonych za bezprawne i przestępcze. Wkrótce komisja Rady Najwyższej wydała dokument zakładający pełną rehabilitację polityczną narodu krymskotatarskiego. W dokumencie tym uznano prawo do powrotu Tatarów na Krym. Jednakże kwestii Tatarów krymskich nie można uznać za ostatecznie rozwiązaną. Po dziesięciu latach od rozpoczęcia masowej repatriacji szczególnie dotkliwy jest problem bezrobocia i braku mieszkań. Wiele osób do tej pory nie otrzymało obywatelstwa ukraińskiego ${ }^{20}$.

W rozważaniach na temat kwestii narodowościowej Ulicka nie zapomina również o Żydach. Żydem jest nie tylko mąż Medei, ale także Alik Szwarcman, Goldberg i jego synowie. Starając się złagodzić skomplikowaną tematykę antysemityzmu, Ulicka sięga do żydowskich anegdot: mąż Medei, wychodząc z drewnianej „toalety”, zwykł np. mawiać: Wychodzac stąd, sprawdź, czy masz czyste sumienie (s. 43), pamiętając jednak, że Żyd stał się na terenie ZSRR ideałem „wroga uniwersalnego", któremu można przypisać wszystkie winy i wady. Było to zastanawiające, zwłaszcza jeśli przypomnimy sobie, że Żydzi odegrali dużą rolę w narodzinach komunizmu, że początkowo zasiadali w najwyższych władzach partii bolszewickiej ${ }^{21}$. Odpowiedź na pytanie, co urzekło Żydów w idei socjalistycznej, nie jest prosta. Złożyło się na to szereg czynników. Przede wszystkim głoszone przez marksistów hasła internacjonalistyczne były dla ludności nieposiadającej swego stałego miejsca bardzo atrakcyjne ${ }^{22}$. Marksowska teoria rewolucji światowej kładła nacisk na zniesienie sprzeczności klasowych oraz optowała za zakończeniem konfliktów o podłożu narodowym, co, rzecz jasna, bardzo Żydom odpowiadało $^{23}$. Historia, która nie szczędziła Żydom doświadczeń dyskryminacji i ucisku, przyczyniła się w znacznym stopniu do popularności ideologii, której głównym celem była walka w obronie słabych i uciskanych, a właśnie za takich część Żydów się uważała i dzięki temu mogła się solidaryzować z innymi ofiarami niesprawiedliwości. Rzecz ciekawa jednak, że zjawisko to dotyczyło również bogatych Żydów, których pozycja, wydawać by się mogło, jest niezachwiana ${ }^{24}$. Dla Aleksandra Sołżenicyna udział Żydów w rewolucyjnym zrywie był, wbrew głoszonym hasłom, odcięciem się

20 Stownik dysydentów..., s. 724.

21 B. Olszewska-Dyoniziak, Antropologia totalitaryzmu europejskiego XX wieku, Wrocław 1999, s. 143.

22 K. Duda, Żydzi i religia w okresie bolszewickim. „Dwieście lat razem” Aleksandra Sotżenicyna, [w:] Stowianie i ich konfesje, red. L. Suchanek, Kraków 2010, s. 158, Prace Komisji Kultury Stowian PAU, 6.

23 H. Haumann, Historia Żydów w Europie Środkowej i Wschodniej, przeł. S. Jenne, Warszawa 2000, s. 176 .

24 A. Kainer, Żydzi a komunizm, „Krytyka” 1983, nr 15, s. 226. 
od odpowiedzialności historycznej, a także od własnej narodowej i duchowej tradycji, co więcej - stanowił początki zakorzeniania się w nowej kulturze ${ }^{25}$. Siergiej Buthakow stwierdził w związku z powyższym: „Duchowe oblicze żydostwa w radzieckim bolszewizmie wcale nie jest wizerunkiem Izraela... To jest właśnie w samym Izraelu stan strasznego duchowego kryzysu z towarzyszącym mu zezwierzęceniem" ${ }^{\text {"2 }}$. Jednakże, na przekór nadziejom żydowskich maksymalistów, przewrót bolszewicki oznaczał także krach kultury i religii żydowskiej. Ograniczono przyjmowanie Żydów na uniwersytety, nie przyjmowano ich również do służby dyplomatycznej, usuwano z sądów i prokuratury, ograniczano ich udział w przedsiębiorstwach. I tak np. w przypadku Alika Szwarca (Medea i jej dzieci) zdawanie na studia wygladato jak walka $z$ pięciogtowym smokiem [...]. Egzaminy zdawat komisyjnie, po odwotaniu się, bo byt święcie przekonany, $\dot{z}$ e nie może mieć oceny niższej niż piątka, wyktadowcy natomiast bardzo dobrze wiedzieli, komu ich stawiać nie moga (s. 272).

Walka z kosmopolityzmem stała się w istocie swej walką z Żydami. Słowa „Żyd”, „kosmopolita”, „syjonista” odczytywano jako synonimy. Nie mogło więc również u Ulickiej zabraknąć komentarzy związanych z tzw. spiskiem lekarzy kremlowskich. Wprowadzone zostają np. do powieści Przypadek doktora Kukockiego poprzez następujący fragment: W styczniu 1953 w catym kraju odbywaty sie zebrania oburzonych obywateli, a w ochronie zdrowia przedsięwzięcia tego rodzaju organizowane byty ze szczególnym zapatem. Wszyscy zajmujacy znaczniejsze stanowiska byli obowiązani się wypowiedzieć i potępićprzestępców. Po raz pierwszy Pawta Aleksiejewicza oświecita prosta myśl, że wszystkich lekarzy, co do jednego, wciaga się we wspótudziat w haniebnym oskarżeniu. On sam nie miat najmniejszych wątpliwości co do catkowitego braku winy lekarzy. Pawet wpadt w gtęboka depresję i po raz pierwszy w życiu zacząt myśleć o samobójstwie... ${ }^{27}$. Spisek lekarzy związany był, jak już dziś wiadomo, z następnym etapem planowanej czystki. W styczniu 1953 r. aresztowano pod zarzutem zamordowania Żdanowa i popełnienia innych zbrodni antyradzieckich wielu kremlowskich lekarzy, w większości noszących żydowskie nazwiska. Było to posunięcie, które mogło posłużyć, podobnie jak wcześniej morderstwo Kirowa, za pretekst do przeprowadzenia zakrojonej na coraz większą skalę czystki „zdrajców” pracujących na rzecz amerykańskiego imperializmu i syjonizmu oraz dążących do zniszczenia międzynarodowego komunizmu. W napiętej sytuacji wytworzonej wojną koreańską i groźbą remilitaryzacji Niemiec czystka prowadzona na taką skalę niewątpliwie miała też odegrać rolę - podobnie jak terror roku 1937 - czynnika mobilizacji psychologicznej narodu w obliczu poważnego kryzysu międzynarodowego ${ }^{28}$.

Za pretekst do aresztowania lekarzy, o czym pisze Ulicka, posłużył donos rentgenologa kremlowskiego szpitala, doktor Lidii Timaszuk, pracującej jednocześnie dla MGB. Oskarżonych poddano bestialskim torturom, po których przyznali się do udziału w spi-

\footnotetext{
А. Солженицын, Авести лет вместе, ч. 2, Москва 2002, s. 221.

С. Бупгаков, Христианство и еврейский вопрос, Париж 1991, s. 125.

27 L. Ulicka, Przypadek doktora Kukockiego, przet. B. Reszko, Warszawa 2006, s. 139.

28 M. Malia, Sowiecka tragedia..., s. 348.
} 
sku, mającym na celu zgładzenie przywódców partii i państwa, a także najwyższego dowództwa wojskowego, poprzez stosowanie umyślnie nieprawidłowych metod leczenia. Oskarżenie wyglądało tak nieprawdopodobnie, że nawet minister bezpieczeństwa Abakumow zawahał się, gdy przyniesiono mu „zeznania” podpisane przez zaszczutych lekarzy. Michaił Heller i Aleksander Niekricz piszą: Sprawe przedstawiono Stalinowi, który nie tylko nakazat jej dalsze prowadzenie, ale też polecit bić oskarżonych tak dtugo, aż się do wszystkiego nie przyznają ${ }^{29}$. Dodajmy, iż prowokatorka Timaszuk została odznaczona Orderem Lenina. Przez cały kraj natomiast przetoczyła się fala protestów potępiających lekarzy-morderców, protestów, w którym żadną miarą uczestniczyć nie chciał uczciwy, ale nazbyt idealistyczny fikcyjny doktor Kukocki.

Historia sama jednak dopisała finał tej bulwersującej sprawy. Już po śmierci Stalina, 4 kwietnia 1953 r., opublikowano bez jakichkolwiek komentarzy komunikat Ministerstwa Spraw Wewnętrznych ZSRR, iż sprawa „zabójców w białych fartuchach” była prowokacją spreparowaną przez kierownictwo dawnego Ministerstwa Bezpieczeństwa Państwowego i że oskarżeni lekarze są niewinni.

Wraz z postaciami Alika Szwarca (Medea i jej dzieci), młodszego z braci Goldbergów (Przypadek doktora Kukockiego) oraz Daniela Steina (Daniel Stein - ttumacz) w twórczości Ulickiej pojawia się temat emigracji żydowskiej. Wymienieni bohaterowie są przedstawicielami tzw. trzeciej fali emigracji rosyjskiej. Jak pisze Lucjan Suchanek: Trzecia fala emigracji rozpoczęta się, gdy Związek Radziecki byt w petni rozwoju, lecz zaczęty się w tym monolicie pojawiać pierwsze rysy. Jej zasadnicza cecha. byto to, że w olbrzymiej większości objęta Żydów, którzy wyjeżdzali tysiacami nie tylko do Izraela, ale również do wielu krajów Europy i Ameryki. Roczna liczba emigrantów, nie tylko żydowskiego pochodzenia, wahata się od kilku do kilkudziesięciu tysięcy. W 1971 r. opuścito Zwiazek Radziecki 15 tys. obywateli, a w 1972, kiedy Stany Zjednoczone przyznaty radzieckim Żydom emigrantom status uciekinierów politycznych, wyjechato 35 tys. ${ }^{30}$

Spoiwem łączącym wszystkie ukazane na kartach powieści narody i nacje jest tytułowa Medea. Nie ma pochodzenia rdzennie rosyjskiego: Medea Mendez, $z$ domu Sinopli, byta ostatnia [...] rodowita Greczynka w rodzinie, która od niepamiętnych czasów zamieszkiwata taurydzkie wybrzeże przypominające Helladę (s. 5). Nadmieńmy, że Grecy pontyjscy (Pontowie), do których należy Medea, zamieszkiwali tereny Pontu od czasów antycznych. Pod koniec I wojny światowej na tym terenie powstała grecka Republika Pontyjska. Rząd Eleftheriosa Wenizelosa, realizując politykę Wielkiej Idei, dążył do przyłączenia jak największej części terenów zamieszkiwanych przez Greków od czasów starożytnych. Idea ta nie mogła jednak dotyczyć Pontu, jako zbyt oddalonego od Grecji. Z tego powodu pojawiła się koncepcja federacji z sąsiednią Armenią (w traktacie z Sèvres ustalono, że rejon ten będzie częścią Armenii), która wywołała drastyczną reakcję turecką w formie najpierw deportacji i eksterminacji Ormian (przedstawia to

29 M. Heller, A. Niekricz, Utopia u wtadzy..., s. 167.

30 L. Suchanek, Emigracja rosyjska XX wieku, [w:] Rosjoznawstwo. Wprowadzenie do studiów nad Rosja, red. tenże, Kraków 2004, s. 393, Prace Katedry Rosjoznawstwa UJ, 7. 
również Ulicka), a następnie Greków pontyjskich. Najnowsze opracowania wskazują, że wymordowanych zostało wówczas 250 tys. mieszkańców Pontu ${ }^{31}$. Potomkowie prawosławnych uchodźców z Pontu, często wciąż kultywujący tradycje kulturowe i językowe, zamieszkują dziś głównie Grecję, USA oraz wybrzeża Morza Czarnego na terenach byłego ZSRR.

Przywiązana do tradycji pontyjskiej Medea potrafi i chce skupić wokół siebie swoich ormiańskich, żydowskich, litewskich, rosyjskich i koreańskich potomków, szanując ich odrębność, język, pochodzenie, wyznanie... Jak pisze Tadeusz Paleczny w książce Interpersonalne stosunki międzykulturowe: $W$ relacjach rodzinnych, pomimo spotecznie $i$ kulturowo wyznaczonej roli ojca czy matki, dzieci często wyróżniaja jedno z rodziców, albo jeszcze kogoś innego, na przyktad ciotkę czy wujka, ze względu na osobiste przymioty takiej osoby. Dystans osobisty to inaczej rzecz ujmujac, "pole aury osobistej" cztowieka. Aure tę wyznacza wyglad, wiek, pteć, kolor skóry, osobisty urok i czar, sposób reagowania na innych, poczucie wtasnej wartości i pewności, które koreluje się z zajmowana spoteczna pozycją ${ }^{32}$. Siedemdziesięciosiedmioletnia Medea byłaby więc, zgodnie z ustaleniami Margaret Mead ${ }^{33}$, przedstawicielką kultury prefiguratywnej, w której obrębie młodzi uczą się od starych, potrzebują ich wiedzy, doświadczenia, mądrości. Medea będzie więc najstarszą reprezentantką pokolenia. Przez to ostatnie rozumiemy, zgodnie z ustaleniami Lidii Liburskiej, zbiorowość o cechach grup rówieśniczych, charakteryzującą się zbieżnością norm, wartości, postaw, motywacji, interesów, realizowanych przez styl życia wzorców zachowań. Pokolenie cechuje się własną tożsamością, czyli symboliczną przynależnością do czasowych i terytorialnych segmentów rzeczywistości społecznej, oraz wspólnym przeżyciem pokoleniowym ${ }^{34}$.

Medea nie ingeruje w spory młodego pokolenia, nie ocenia, wszelkie problemy stara się rozwiązać poprzez konstruktywny dialog, będąc dowodem na to, że człowiek w swoim życiu buduje różnorodne relacje: ze światem rzeczy, zwierząt, a przede wszystkim z ludźmi. Nasze jednostkowe „ja” jest zawsze ku czemuś czy komuś skierowane: poznaje otaczający świat, doświadcza go, przeżywa różne sytuacje egzystencjalne, poszukuje ludzi. Relacje kształtują człowieka, prawdopodobnie nie ontologicznie, ale psychicznie i egzystencjalnie. Istnienie człowieka jest zatem wspólistnieniem z innymi. Bytowość człowieka nie sprowadza się do faktu relacji, ale w nich się wypowiada i finalizuje. Filozofia dialogu jest opozycją ideologii walki, konfliktu i antagonizmów ${ }^{35}$. Medea jest w związku z tym zaprzeczeniem infantylnej natury homo sovieticusa, a potwierdzeniem wewnętrznego piękna, tkwiącego w rosyjskim prawiedniku - człowieku sprawiedli-

31 The Australian Institute for Holocaust and Genocide Studies, [online] http://www.holocaust-genocide/articles/studies/76599, 21 II 2013.

32 T. Paleczny, Interpersonalne stosunki międzykulturowe, Kraków 2007, s. 33.

33 M. Mead, Kultura i tożsamość. Studium dystansu międzypokoleniowego, przeł. J. Hołówka, Warszawa 1978, s. 81, Biblioteka Socjologiczna.

34 L. Liburska, Dziedzictwo idei - pokolenie „biesów” a ponowoczesność, [w:] Fiodor Dostojewski i problemy kultury, red. A. Raźny, Kraków 2011, s. 79, Prace Katedry Rosyjskiej Kultury Nowożytnej UJ.

35 S. Kowalczyk, Z refleksji nad cztowiekiem. Cztowiek, spoteczność, wartość, Lublin 1995, s. 48. 
wym $^{36}$. Zgodnie z tym, co pisze Martyna Kowalska: Stownikowa definicja terminu „prawiednik" odwotuje się do dwóch znaczeń. Pierwsze ma wymiar religijny i oznacza cztowiek a prawego, bez grzechów, żyjacego w zgodzie z przykazaniami, moralnymi nakazami jakiejśr religii. Drugie, wykraczajace poza sferę religijna, określa cztowieka, w swoich uczynkach $i$ zachowaniu, niegrzeszącego względem wymogów moralności. W języku cerkiewnym prawiednik oraz majacy tożsame znaczenie sprawiedliwy, bogobojny, światobliwy, pobożny [...], odnosi się do świętych, przebywajacych poza murami klasztornymi oraz pustelniami, prowadzacych normalne życie rodzinne i spoteczne ${ }^{37}$.

Nawiązując szczery, bezpośredni kontakt nawet z obcymi, szanując inność i odmienność, Medea staje się również elementem sprzeciwu wobec utopii komunistycznej realizowanej w państwie bolszewików, a opartej na braku zaufania, podejrzliwości i wrogości wobec innych. W ten sposób także Ulicka podpisuje się pod niekwestionowanym już dzisiaj stwierdzeniem, iż naczelnym założeniem komunistycznego eksperymentu utopijnego było stworzenie nowej istoty, która zyskała miano homo sovieticus. W utworach Ulickiej wyposażony on zostaje w taki mniej więcej zestaw charakterologiczny: cechuje go brak uzdolnień i zainteresowań politycznych, bezwzględne posłuszeństwo wobec sił kierowniczych, bierny udział w życiu państwowym. Taki człowiek jest jedynie narzędziem w rękach partii, nie będzie się przeciwstawiał reżimowi, nie zdobędzie się na jego krytyczną ocenę, biernie poddaje się każdej sile politycznej, która aktualnie zdobywa przewagę ${ }^{38}$. Człowiek traci swoją indywidualność, staje się częścią kolektywu, który za niego myśli i podejmuje decyzje. Spowodował zatem materializm komunistyczny pomniejszenie, zdeklasowanie i depersonalizację człowieka. Duch bowiem wedle światopoglądu marksistowskiego jest tylko częścią materii. Stąd zamiast zmierzać do samodzielnego, własnym wysiłkiem osiąganego celu podlega tym samym co materia prawom ewolucji. W ten sposób człowiek jako podmiot o odrębnej osobowości został niejako ściągnięty z piedestału, na jakim stawiało go chrześcijaństwo ${ }^{39}$. Lucjan Suchanek w artykule Cztowiek radziecki i naród radziecki. Eksperyment ideologiczny i etniczny zanotowat: Wszystkie te zamiary kreowania cztowiek a wedtug wyobrażeń ideologów oparte byty na fatszywej tezie antropologicznej, na btędnym wyobrażeniu, czym jest cztowiek, w którym nie dostrzegano osoby, poddają go nadmiernemu uspotecznieniu ${ }^{40}$.

W wykreowanym przez Ulicką świecie tylko ludzie nietuzinkowi (tacy jak Medea, Sonieczka, Kukocki, Daniel...), pasjonaci, artyści nie poddają się presji komunistycznego monstrum. Chroni ich dobrze wykonana praca, żywioł muzyki, malarstwa, a często także - miłość, ale przede wszystkim wolność wewnętrzna.

36 Na ten temat zob. więcej: M. Kowalska, Aleksander Sotżenicyn. Homo sovieticus i cztowiek sprawiedliwy, Toruń 2011, W Kręgu Problemów Emigracji.

37 Tamże, s. 35.

38 B. Olszewska-Dyoniziak, Antropologia totalitaryzmu..., s. 188-189.

39 H. Dembiński, Kolektywizm i totalitaryzm jako zasady życia, [w:] Bolszewizm. Praca zbiorowa, Lublin 1938, s. 71, Towarzystwo Wiedzy Chrześcijańskiej. Uniwersyteckie Wyktady dla Duchowieństwa, 3.

40 L. Suchanek, Cztowiek radziecki i naród radziecki. Eksperyment ideologiczny i etniczny, [w:] Wspótcześni Stowianie wobec wtasnych tradycji i mitów. Sympozjum w Castel Gandolfo, 19-20 sierpnia 1996, red. M. Bobrownicka, L. Suchanek, F. Ziejka, Kraków 1997, s. 71. 
Dla Medei ważniejsza od mitycznie pojmowanego państwa jest rodzina, jedyna prawdziwa, bo spojona więzami krwi, wspólnota. Rodzina okazuje się, w związku z powyższym, cząstką społeczeństwa, której wartość i spoistość oparte są na miłości. Walor rodziny jest konsekwencją tego, że jest ona miejscem, w którym splatają się ściśle ze sobą różne formy miłości: oblubieńczo-małżeńska, rodzicielska, synowska, bratersko-siostrzana. Wymienione formy miłości pojawiają się w każdej rodzinie dwupokoleniowej. Istnieją obok tego (tak jak na kartach powieści Ulickiej) rodziny wielopokoleniowe, w których ważną rolę odgrywają dziadkowie i babcie, a także bliżsi i dalsi krewni. Taka makrorodzina jest rodem, który swoim członkom daje poczucie ciągłości, tożsamości, bezpieczeństwa i wzajemnego wsparcia ${ }^{41}$. Społeczność rodziny jest szkołą człowieczeństwa. Takim centrum prywatności, ostoją tradycji staje się dom Medei: tylko tutaj czuję sie jak u siebie w domu (s. 28) - powie krewny z Moskwy, Georgij. W teodozyjskim domu Medei kultywuje się tradycję i nie łamie akceptowanych przez wszystkich zwyczajów: przed rozpoczęciem wypoczynku nad morzem wszyscy krewni udają się na miejscowy cmentarz, aby „odwiedzić” zmarłych przodków, po zachodzie słońca nie czerpie się wody ze studni, nikt bez zaproszenia nie wchodzi do pokoju Medei, dzieci biesiadują przy osobnym stole... Urszula Trojanowska słusznie więc wysnuwa konkluzję, że słowo „dom” bezspornie należy do pojęć-kluczy kultury, jako że wyznacza krąg elementarnych doświadczeń każdego człowieka i tkwi w samym centrum powszechnie uznawanego systemu wartości obok takich pojęć, jak matka, rodzina, kraj, ojczyzna, z którymi jest powiązane siecią semantycznych zależnoścíi ${ }^{42}$. Dla wielu uczonych związek domu ze sferą transcendentną wydaje się niewątpliwy, ponieważ budowanie i zasiedlanie każdej siedziby jest zawsze równoznaczne z nowym życiem i początkiem, który niezmiennie odtwarza początek pierwotny - boski akt stworzenia świata. Dom nie jest więc maszyna do mieszkania ${ }^{43}$, lecz wszechświatem, który cztowiek sobie buduje, naśladujac wzorcowe dzieto bogów-kosmogonię $e^{44}$.

Ród Medei stanowi mieszankę wielokulturową: tytułowa bohaterka-Greczynka jest żoną Żyda tak samo jak jej „cioteczna wnuczka” - Masza, Georgij to potomek ormiańsko-greckiego małżeństwa, Gildjas - syn Litwinki i Rosjanina... Oczywiście, że takie wymieszanie ludności było celem państwa, dążącego do rusyfikacji, ale w dużej mierze okazało się eksperymentem nieudanym: nie zdołano zatomizować rodziny ani zastąpić jej przez oddanie abstrakcyjnemu państwu-partii, zaś mieszane małżeństwa doprowadziły raczej do wzbogacenia niż zatomizowania rodziny. Zgodnie bowiem z tym, co pisze Tadeusz Paleczny: W'środowisku mieszanym kulturowo, w którym występuje wyraźna tendencja do taczenia, syntezy, tworzenia nowej, szerszej od dotychczasowej tożsa-

41 S. Kowalczyk, Cztowiek a spoteczność. Zarys filozofii spotecznej, Lublin 1994, s. 271.

${ }^{42}$ U. Trojanowska, Archetyp domu w dwudziestowiecznej literaturze rosyjskiej. Lidia Czukowska, Jurij Trifonow, Anatolij Pristawkin, Kraków 2008, s. 7, Rosja - Myśl, Stowo, Obraz.

43 M. Eliade, Świat, miasto, dom, [w:] tenże, Okultyzm, czary, mody kulturalne. Eseje, przeł. I. Kania, Kraków 1992, s. 27.

44 Tamże, s. 30. 
mości grupowej catości kulturowej, zwiększa się szansa na przekroczenie barier religijnych, jezykowych czy rasowych ${ }^{45}$.

Skoro zatem tytułowa bohaterka jest łącznikiem, spoiwem rodu, zapewniającym mu bezinteresowną miłość, trwałość, to dlaczego autorka nadała jej imię mitologicznej dzieciobójczyni? Z jednej strony chodzi, co oczywiste, o zwrócenie uwagi na greckie pochodzenie rodziny, choć odwołań do mitologii greckiej będzie tu niewiele: $n$ p. Butonow nazwany zostanie Odyseuszem (choć w tym przypadku autorka wykorzysta sarkazm: bohater powraca bowiem do żony-Penelopy po wielu romansach z przypadkowymi kobietami), raz tylko na przestrzeni całej powieści znajdziemy bezpośrednie odniesienie do mitycznego dziedzictwa: Medea nauczyta ją [Aleksandrę - K.D.] postugiwaí się nienagannym jezykiem, a po pontyjskich żeglarzach otrzymata chyba krople szlachetnej krwi i zaszczytne podobieństwo z królowymi, zwróconymi na wszystkich malowidtach z profilu, które przędty wtóczkę, tkaty chitony i robity ser dla swych mężów, królów Itaki i Myken (s. 157).

Wydaje się, iż mitologię potraktowała Ulicka w sposób instrumentalny, w określonym celu. Medea kocha swych potomków, Odyseusz jest zdrajcą, Afrodyta - wątpliwej urody kobietą wyłaniającą się z lodowatej wody..., albowiem bogów z Olimpu, herosów i bóstwa zastąpili radzieccy „bogowie i herosi” zasiadający na Kremlu, ofiarujący nie nektar życia i napój wiecznej młodości i szczęścia, ale królestwo łagrów, biedę i wszechwładny strach. Książka Ulickiej nie jest zatem zbiorem mitów rozumianych jako przekazywane przez starożytną tradycję grecką opowieści o bogach i herosach, wyjaśniających miejsce człowieka w świecie oraz samo funkcjonowanie świata, jego stworzenie $\mathrm{i}$ historię. Z mitologii bowiem czerpano wiedzę o świecie i rozwijano na tej podstawie normy etyczne wyznaczające miejsce człowieka w ustalonym porządku. Wiedza płynąca z mitów nie stanowiła jednak nigdy „prawdy objawionej” i otwarta była na dyskurs, polemikę i krytykę. Sama zaś starożytna religia grecka, chociaż nie sposób o niej mówić w oderwaniu od mitologii będącej jej elementarną częścią składową, opierała się w znacznym stopniu na ortopraksji (jedności praktyk religijnych), nie zaś ortodoksji (jedności poglądów) ${ }^{46}$.

W ZSRR zaistniała natomiast inna odmiana mitologii - mitologia radziecka, odwołująca się nie do rozumu, a do emocji człowieka, niepozwalająca zatem na racjonalizację problemów oraz analizę otaczającej rzeczywistości. Ulicka zdaje się wykorzystywać ten rodzaj mitologii w celu jej dyskredytacji, podkreślając, że choć jej wpływ na naród był duży, to jednak nie udało się stworzyć z ludzi ideologicznego monolitu. W Kraju Rad, po raz pierwszy w historii na taką skalę, miało miejsce, trwające kilka pokoleń, doświadczenie tworzenia mitów - irracjonalnych objaśnień świata i człowieka dla osiągnięcia praktycznych potrzeb władzy i zamiany ich w przypadku nieprzydatności lub przestarzałości ${ }^{47}$. I tak, mit rewolucji zamieniony został mitem państwa-partii, a następnie mi-

45 T. Paleczny, Interpersonalne stosunki..., s. 48.

46 Mitologia grecka, Wikipedia, s. 7, [online] http://pl.wikipedia.org/w/index.php?title=Mitologia_ grecka\&oldid=33548058, 23 II 2013.

47 M. Heller, Maszyna iśrubki. Jak hartowat się cztowiek sowiecki, Warszawa 1989, s. 211. 
tem Wodza - ojca narodu. Nadmieńmy, iż Leonid Breżniew (a właśnie w czasach jego rządów rozgrywa się akcja powieści Medea i jej dzieci) znalazł doskonałą rytualną formułę mitu nieśmiertelności Wodza: podczas wymiany legitymacji partyjnych wręczył legitymację numer 00000001 Leninowi, legitymację numer 2 przyznając sobie ${ }^{48}$.

Najmniej konkretnym z mitologemów wchodzących w skład mitu Państwa jest naród. Samo państwo, a także partia mają konkretne formy, realne struktury, które wypełniają funkcje mitotwórcze. Naród struktury nie posiada, jeśli nie liczyć granicy państwowej - zamka na drzwiach raju (według wyrażenia Nikity Chruszczowa), przeszkadzającego narodowi roztopić się w ludzkości. Określenie narodu precyzowane było przez ekspertów-ideologów, którzy decydowali, kto jest członkiem narodu, a kto nie wchodzi w jego skład. W połowie lat 60. minionego stulecia wchodzi w użycie termin „państwo ogólnonarodowe”, ojczyzna „nowej historycznej wspólnoty ludzi - narodu radzieckiego" ${ }^{49}$. Końcowa hipostaza mitu państwa radzieckiego jako „ogólnonarodowego państwa narodu radzieckiego" idealnie wypełnia pierwszą funkcję mitu - wyjaśnia rzeczy i wszechświat, nie korzystając z rozumu. „Państwo ogólnonarodowe” reprezentować miało wyższą formę demokracji, której inicjatorem i głównym gwarantem jest partia bolszewicka. Państwo radzieckie to równocześnie „państwo ogólnonarodowe”, w którym wszystkie narody są równe, ale jednocześnie - to państwo rosyjskie, w którym naród rosyjski jest „pierwszym wśród równych”. O możliwości zaprogramowania genialności, a przede wszystkim o narodzie wypowiadają się również bohaterowie Ulickiej. Do takich należy np. Ilja Goldberg (Przypadek doktora Kukockiego): ostatnia idea Goldberga, który po trzech wyrokach spędzonych w tagrach utracit inteligenckie poczucie winy wobec narodu, spoteczeństwa, rodzimej wtadzy sowieckiej, polegata na tym, że ta socjogenetyczna jednostka, przed rewolucja nazywajaca sie "narodem rosyjskim”, w ciagu prawie pięćdziesięciu lat wtadzy sowieckiej przestata istnieć w rzeczywistości, a obecna ludnośc Zwiazku Sowieckiego, noszaca nazwe "narodu sowieckiego", jest w istocie nowa socjogenetyczna jednostką, różniaca się gtęboko od jednostki wyjściowej pod względem wielu parametrów - fizycznych, psychofizycznych, moralnych... ${ }^{50}$.

Przyczyny wyradzania się narodu związane są, zdaniem Goldberga, z kolejnymi czystkami, falami terroru, zmuszaniem do emigracji, głodem, aresztowaniami, osadzaniem $\mathrm{w}$ więzieniach. W ten sposób wytrzebiono kwiat narodu rosyjskiego: najpierw białą armię, w 1922 r. ojczyznę musieli opuścić wybitni intelektualiści, potem (na skutek kolektywizacji) zginęli najbardziej aktywni chłopi, a całą tę tragedię spowodowała eksterminacja duchowieństwa ${ }^{51}$. Najbardziej „,widocznym” członkiem społeczeństwa stał się zatem szary, „uśredniony” obywatel. Goldberg dowodzi: Skoro ewolucja byta nakierowana na utrzymanie sięprzy życiu, mamy prawo postawićpytanie: jakie cechy dawaty pojedynczemu osobnikowi szansę na przetrwanie? Rozum? Talent? Honor? Poczucie wtasnej godności? Surowa postawa moralna? Nie! Te wszystkie cechy szkodzity przetrwaniu.

\footnotetext{
Tamże, s. 218.

Tamże, s. 231.

$50 \quad$ L. Ulicka, Przypadek doktora..., s. 322-323.

$51 \quad$ K. Duda, Wspótczesna literatura rosyjska..., s. 61.
} 
Ich nosiciele albo opuścili kraj, albo byli planowo eksterminowani. A jakie cechy sprzyjaty przetrwaniu? Ostrożność. Skrytość. Zdolność do obtudy. Chwiejność moralna. Brak poczucia wtasnej godności. W ogóle każda wyraźna cecha sprawiata, że dany cztowiek się wyróżniat i byt zagrożony ciosem. Szary, przeciętny, trójkowicz - można powiedzieć, byt $w$ znacznie lepszym potożeniu ${ }^{52}$.

Nie należy jednak przy tym tracić z pola widzenia faktu, iż naród rosyjski ucierpiał w czasie trwania komunizmu nie mniej niż inne narody. W czasie kolektywizacji Rosjanie uznani za kułaków zsyłani byli na Syberię, chłopów rosyjskich, o których już wspominano, z powrotem "przywiązano do ziemi”, buntujących się zamykano w więziennych zakładach psychiatrycznych bądź osadzano w łagrach - przykłady można by mnożyć. Aleksander Sołżenicyn, już po upadku ZSRR, odnotowat: Ludzie żyjacy w swoich miejscowościach, w których oni sami, a przed nimi ich ojcowie $i$ dziadowie spędzili cate życie, obudziwszy się pewnego dnia, nagle dowiedzieli się, że mieszkaja - za granica, że sq niepożadanymi, odpychanymi, a nawet znienawidzonymi cudzoziemcami. [...]. Sowiecka "przyjaźń narodów", o której styszeliśmy tyle ód i ballad, w mgnieniu oka wyszczerzyta zęby i okazata się wrogościa, która byta ttumiona, ale, jak widać, nigdy nie ustata ${ }^{53}$. Ulicka nie jest jednakże w swych sądach tak kategoryczna. Przedstawia na kartach swej powieści wielu szlachetnych, uczciwych Rosjan, ale według niej linia podziału biegnie nie między narodami, a między ludźmi-jednostkami, ludźmi-osobami. Dlatego też bohaterów różnicuje autorka głównie na mocy ich postaw wobec wartości uniwersalnych i mechanizmów ich zachowań w sytuacjach granicznych: cierpienia, choroby, śmierci.

Uczucia narodowe, jak zaświadcza historia minionych kilkudziesięciu lat, były, wespół z religią, najważniejszymi punktami oparcia, pozwalającymi sprzeciwiać się presji radzieckiej ideologii i równocześnie włączeniu w magiczny krąg radzieckiej mitologii. Dlatego prowadzono walkę z nacjonalizmami narodów nierosyjskich, które nie mogą być wykorzystane dla mitotwórstwa, a także z tymi religiami, które nie pozwalają na zasymilowanie się i odmawiają służenia państwu.

Odmawiano prawa istnienia religii, gdyż najbardziej pożądaną wiarą miała być wiara komunistyczna (tzw. nowa religia), a miejsce Boga zajmowali kolejni sekretarze KC KPZR. Wszechwładna stała się więc idolatria, kreowanie ziemskich bożków, idoli, którym oddawano cześć, którym stawiano pomniki (np. Pawlik Morozow) bądź których miejsca wiecznego pochówku stawały się sanktuariami odwiedzanymi przez rzesze wiernych (Mauzoleum Lenina). Idolatria może mieć różne formy, bardziej czy mniej zawoalowane. Jest on a wyzwaniem dla wiary w Jedynego Boga, ale równocześnie gtęboko określa i naznacza postawę ludzkq ${ }^{54}$. W praktyce oznacza to postawę zamknięcia się na drugiego człowieka, obojętności wobec zła.

Według Rafała Imosa poza funkcjonalnymi analogiami marksizm-leninizm w swej realizowanej postaci spetnia kryteria uniwersalistycznych religii zatożonych, a jego twórcom

52 L. Ulicka, Przypadek doktora..., s. 325.

53 A. Sołżenicyn, Rosja wapaści, przeł. J. Zychowicz, Warszawa 1999, s. 42.

54 J.S. Gajek, Chrzésijańska wiara w Jedynego Boga, [w:] Wiara w postawie ludzkiej. Praca zbiorowa, red. W. Słomka, Lublin 1991, s. 70, Prace Wydziatu Teologicznego KUL, 77. Homo Medians, 6. 
nie sposób odmówić cech proroków ${ }^{55}$. Ponadto dzieje komunizmu, począwszy od założycieli, poprzez kwestię sukcesji i kształtowanie ortodoksji, po zsekularyzowane realia breżniewowskiego „zastoju”, wpisują się w pełni w ewolucyjne prawidłowości rozwoju religii założonych, choć rzeczywiście zdają się zjawiskiem efemerycznym na ich tle.

Medea nie narzuca swej wiary (prawosławia) zateizowanemu młodemu pokoleniu, więcej: uznaje prawo do istnienia innych religii, będących wszak jednym z podstawowych wyznaczników kultur. Dlatego biblijne Na początku byto Stowo... jest dla niej równie istotne, jak mityczne Na początku byt Chaos..., Biblia natomiast nie wyklucza istnienia i poszanowania dla zwojów Tory, Koranu czy obrządków pogańskich. Zaznaczyć trzeba jednak, że sama bohaterka jest osobą głęboko wierzącą: regularnie chodzi do cerkwi, czci święta prawosławne, czyni znak krzyża, docenia wartość modlitwy, która $z$ istoty swej antropologiczna - ksztattuje cztowieka jako cztowieka Bożego, ponieważ w czasie modlitwy wznosi się on w Duchu przez Syna do Ojca i wchodzi w ten sposób $w$ relacje Trójcy Swiętej ${ }^{56}$. Tymczasem pełnia człowieka, osiągana podczas modlitwy, ma swą siedzibę w sercu. Możemy więc mówić o mistyce serca. Liturgia ukazuje charakter wspólnotowy modlitwy, a stojący przed ikonami człowiek zostaje umieszczony pośrodku uświęconego kosmosu. Ciekawe, że na kartach powieści bohaterka kilkakrotnie porównana będzie do ikony bądź pokazywana w jej sąsiedztwie. Znaczenie modlitwy dla pontyjskiej Greczynki obrazuje następujący cytat: Póki grzata się woda, Medea sprzątnęta pościel, chowając poduszki i kotdry do kufra przy wezgtowiu tózka i mamrocząc krótkąporanna modlitwę, sktadająca się z doszczętnie wytartych stów, które mimo to pomagaty jej przyjmować każdy nowy dzień z catym jego trudem, zmartwieniami, cudzym pustym gadaniem i wieczornym zmęczeniem, przeżyć go podobnie, bez rozdrażnienia i urazy (s. 43-44). Ikona natomiast, jak wiadomo, zajmuje szczególne miejsce w duchowości rosyjskiej. Co nie znaczy, że wszyscy malarze mieli świadomość takiej teologii ikon, jaka została opracowana później przez teologów i myślicieli rosyjskich. Można jednak twierdzić, że jakaś koncepcja mistyczna była zawsze obecna w malarstwie ikon ${ }^{57}$. Jak pisze Tomasz Špidlík: [...] celem każdego dzieta sztuki jest piękno. Ono zaś [...] polega na zdolności ukazania inności w jedności. Na podstawie gtębi i wielkości tego, co widzimy w, „jedności", która petni funkcje symbolu inności, oceniamy podniosty charakter sztuki. Ikony sa, oczywiście, symbolami materialnymi, ale pozwalaja widzieć to, co jest inne, Theos i Logos, Boża Madrość [...] $w$ dziele zbawienia ${ }^{58}$.

Najważniejsza dla bohaterki wykreowanej przez Ulicką jest jednakże modlitwa czynem, bezinteresowna pomoc niesiona drugiemu człowiekowi, godność oraz dar wybaczania (co niektórzy z jej otoczenia przyjmują nieraz jako naiwność). Po śmierci rodziców Medea opiekowała się rodzeństwem, ciotecznymi wnukami i ich potomkami, czyniąc to nie z obowiązku, lecz powodując się miłością i oddaniem. Wiara jest pan-

\footnotetext{
R. Imos, Wiara cztowieka radzieckiego, Kraków 2007, s. 417.

56 T. Špidlík, Myśl rosyjska. Inna wizja cztowieka, przeł. J. Dembska, Warszawa 2000, s. 337, Bogostowije, 3.

57 Tamże, s. 377.

58 Tamże, s. 378.
} 
cerzem ochronnym Medei, jej tarczą, narzędziem odcięcia się od polityki i zawierzenia zgubnej idolatrii. Jej krewny będzie miał rację, gdy powie: Co dla niej znaczy wtadza? Jest wierzaca, inna wtadzę ma nad sobą. I nigdy nie mów, że ona czegośs się boi [...] (s. 57). Medę̨ określić można niemodnym być może dzisiaj słowem - tolerancyjna. Wiąże się to przede wszystkim z jej postawą wobec męża - Żyda, któremu w obliczu śmierci pomaga wrócić do wiary jego przodków: Zauważyt później, że to catkowicie oderwane od rzeczywistości prawo, nakreślone już $w$ Księdze Wyjsś́ i rozpracowane w catości w Talmudzie, rozpatruje wszystkie możliwe i niemożliwe sytuacje, w jakich może się znaleźć cztowiek, i daje doktadne wskazówki co do zachowania w konkretnych okolicznościach. Wszystkie te, chaotycznie obtożone zakazami, postępowania miaty na celu wytacznie zachowanie świętości życia narodu Izraela i catkowite odrzucenie prawa ziemi kananejskiej (s. 211-212).

Najważniejszym, symbolicznym wyznacznikiem tożsamości kulturowej jest język. Nie tylko odróżnia nas od zwierząt, ale też jest specyficznym, ukształtowanym w świadomości kodem, pozwalającym na wyrażenie myśli, uczuć, emocji oraz ich różnych, subtelnych nieraz, odcieni. Wszyscy bohaterowie książki Ulickiej posługują się, co oczywiste, językiem rosyjskim: nie mogło być inaczej w kraju, w którym w programach szkolnych dla uczniów szkół średnich poświęcano tylko jedną godzinę tygodniowo na naukę języka obcego. Chodziło, co zrozumiałe w kontekście ideologii komunistycznej, o odcięcie mieszkańców ZSRR od przestrzeni informacyjnej Zachodu. Było to również ironicznym nawiązaniem do klasycznych utopii - państw, gdzie nie będzie głodu, chorób, pracy ponad siły... Mądry król Utopus z książki Thomasa More’a kazał odgrodzić swój kraj od reszty świata wysokim ogrodzeniem, aby nie dotarło do niego zło $\mathrm{z}$ zewnątrz ${ }^{59}$. Rolę taką w dwudziestowiecznym Związku Radzieckim miała odgrywać (w odwróconym znaczeniu), ,żelazna kurtyna”.

Uznanie języka rosyjskiego za oficjalny nie przeszkodziło jednak krewnym i przyjaciołom Medei posługiwać się, wypracowanym przez ich przodków, własnym językiem: ormiańskim, litewskim, jidysz oraz pontyjskim. Spadkobierczynią tego ostatniego jest Medea. Zaznaczyć należy, iż język pontyjski to odmiana języka greckiego używana tradycyjnie właśnie na południowych i wschodnich wybrzeżach Morza Czarnego. Język ten zapisywany jest tradycyjną odmianą alfabetu greckiego, w Rosji natomiast cyryli$\mathrm{cą}^{60}$. Języka przodków bohaterowie używają jednak tylko w przestrzeni prywatności. Mimo to dzięki językowi odzyskują poczucie odrębności, niepowtarzalności, a z drugiej strony - silnego związku z tradycją antenatów.

Medea, rosyjski człowiek sprawiedliwy, to nie tylko przewodnik dla moralnych ślepców, to przykład możliwości współistnienia zantagonizowanych nieraz kultur, łącznika między „dawnymi a nowymi czasy”. Z tego zapewne względu powieść wieńczy optymistyczne zakończenie ukryte w słowach narratorki: To cudowne uczucie - należé do rodziny Medei, takiej ogromnej, że nie znasz nawet jej wszystkich cztonków, którzy gubią się w mroku bytego, zmyślonego i tego, co jeszcze przed nami (s. 340).

59 J. Szacki, Spotkania z utopia, Warszawa 2000, s. 15, Stanowiska, Interpretacje, 16.

60 Ponic, [w:] Ethnologue. Languages of the World, red. M.P. Lewis, G.F. Simons, Ch.D. Fennig, Dallas 2014, [online] http://www.ethnologue.com/show_language.asp?code=pnt, 15 I 2013. 


\section{BIBLIOGRAFIA}

Алексеева А., История инакомьслия в СССР. Новейший период, Vilnius-Moskwa 1992.

The Australian Institute for Holocaust and Genocide Studies, [online] http://www. holocaust-genocide/articles/studies/76599.

Букгаков С., Христианство и еврейский вопрос, Париж 1991.

Daszkiewicz W., Wielokulturowość a ideologia multikulturalizmu, „Cywilizacja” 2010, nr 33.

Dembiński H., Kolektywizm i totalitaryzm jako zasady życia, [w:] Bolszewizm. Praca zbiorowa, Lublin 1938, Towarzystwo Wiedzy Chrześcijańskiej. Uniwersyteckie Wyktady dla Duchowieństwa, 3.

Duda K., Andriej Amalrik - rosyjski dysydent, Kraków 2010, Literatura Rosyjska - Emigracja Tamizdat-Samizdat, 15.

Duda K., Wspótczesna literatura rosyjska wobec historii (nowy realizm Ludmity Ulickiej), [w:] Kultura i polityka, red. L. Suchanek, Kraków 2008, Prace Komisji Kultury Stowian PAU, 8.

Duda K., Żydzi i ich religia w okresie bolszewickim. „Dwieście lat razem” Aleksandra Sotżenicyna, [w:] Stowianie i ich konfesje, red. L. Suchanek, Kraków 2010, Prace Komisji Kultury Stowian PAU, 6 .

Eliade M., Okultyzm, czary, mody kulturalne. Eseje, przeł. I. Kania, Kraków 1992.

Fitzpatrick S., Życie codzienne pod rzadami Stalina. Rosja radziecka w latach trzydziestych XX wieku, przeł. J. Gilewicz, Kraków 2012, Historiai.

Gajek J.S., Chrześcijańska wiara w Jedynego Boga, [w:] Wiara w postawie ludzkiej. Praca zbiorowa, red. W. Słomka, Lublin 1991, Prace Wydziatu Teologicznego KUL, 77. Homo Medians, 6.

Haumann H., Historia Żydów w Europie Środkowej i Wschodniej, przeł. C. Jenne, Warszawa 2000.

Heller M., Maszyna i śrubki. Jak hartowat się cztowiek sowiecki, Warszawa 1989.

Heller M., Niekricz A., Utopia u wtadzy. Historia Zwiazku Sowieckiego, t. 2, przeł. A. Mietkowski, Wrocław 1989.

Imos R., Wiara cztowieka radzieckiego, Kraków 2007.

Kainer A., Żydzi a komunizm, „Krytyka” 1983, nr 15.

Kowalczyk S., Cztowiek a spoteczność. Zarys filozofii spotecznej, Lublin 1994.

Kowalczyk S., Z refleksji nad cztowiekiem. Cztowiek, spoteczność, wartość, Lublin 1995.

Kowalska M., Aleksander Sotzenicyn. Homo sovieticus i cztowiek sprawiedliwy, Toruń 2011, W Kregu Problemów Emigracji.

Liburska L., Dziedzictwo idei - pokolenie „biesów” a ponowoczesność, [w:] Fiodor Dostojewski i problemy kultury, red. A. Raźny, Kraków 2011, Prace Katedry Rosyjskiej Kultury Nowożytnej UJ.

Ludmita Ulicka, [online] http://buker.obninsk.ru/h_ulitskaya.

Аюдмила Улицкал - лауреат премии „Букер - 2001”, [online] http://www.ror.ru/culture/ cultarch197_rus!html.

Malia M., Sowiecka tragedia. Historia komunistycznego imperium rosyjskiego 1917-1991, przeł. M. Hułas, E. Wyzner, Warszawa 1994. 
Marciniak W., Rozgrabione imperium. Upadek Związu Sowieckiego i powstanie Federacji Rosyjskiej, Kraków 2004, Arkana Historii.

Mead M., Kultura i tożsamość. Studium dystansu międzypokoleniowego, przeł. J. Hołówka, Warszawa 1978, Biblioteka Socjologiczna.

Mitologia grecka, Wikipedia, [online] http://pl.wikipedia.org/w/index.php?title=Mitologia_ grecka\&coldid $=33548058$.

Olszewska-Dyoniziak B., Antropologia totalitaryzmu europejskiego XX wieku, Wrocław 1999.

Paleczny T., Interpersonalne stosunki międzykulturowe, Kraków 2007.

Ponic, [w:] Ethnologue. Languages of the World, red. M.P. Lewis, G.F. Simons, Ch.D. Fennig,

Dallas 2014, [online] http://www.ethnologue.com/show_language.asp?code=pnt.

Sałajczykowa J., Dziesięciolecie przemian. Proza rosyjska lat 1985-1995, Gdańsk 1998.

Stownik dysydentów. Czotowe postacie ruchów opozycyjnych w krajach komunistycznych w latach

1956-1989, t. 2: Armenia, Azerbejdizan, Biatoruś, Estonia, Gruzja, Litwa, Eotwa, Motdawia,

Rosja, Ukraina i Tatarzy Krymscy, Warszawa 2007.

Солженицын А., Авести лет вместе, ч. 2, Москва 2002.

Sołżenicyn A., Rosja w zapaści, przeł. J. Zychowicz, Warszawa 1999.

Suchanek L., Czlowiek radziecki i naród radziecki. Eksperyment ideologiczny i etniczny, [w:]

Wspótcześni Stowianie wobec wtasnych tradycji i mitów. Sympozjum w Castel Gandolfo, 19-20 sierpnia 1996, red. M. Bobrownicka, L. Suchanek, F. Ziejka, Kraków 1997.

Suchanek L., Emigracja rosyjska XX wieku, [w:] Rosjoznawstwo. Wprowadzenie do studiów nad Rosją, red. tenże, Kraków 2004, Prace Katedry Rosjoznawstwa UJ, 7.

Špidlík T., Myśl rosyjska. Inna wizja cztowieka, przeł. J. Dembska, Warszawa 2000, Bogostowije, 3. Szacki J., Spotkania z utopia, Warszawa 2000, Stanowiska, Interpretacje, 16.

Trojanowska U., Archetyp domu w dwudziestowiecznej literaturze rosyjskiej. Lidia Czukowska,

Jurij Trifonow, Anatolij Pristawkin, Kraków 2008, Rosja - Myśl, Stowo, Obraz.

Ulicka L., Medea i jej dzieci, przeł. R. Bartosik, Warszawa 2004, Klub Interesującej Prozy.

Ulicka L., Przypadek doktora Kukockiego, przeł. B. Reszko, Warszawa 2006.

Вайль П., Генис А., Современная русская проза, Ann Arbor 1982.

Вишневский А., Единая и неделимая, „Полис” 1994, nr 2.

Prof. dr hab. Katarzyna DUDA - pracownik naukowo-dydaktyczny w Zakładzie Antropologii Kultury Rosyjskiej w Instytucie Rosji i Europy Wschodniej na Wydziale Studiów Międzynarodowych i Politycznych UJ. Autorka książek Antyutopia w literaturze rosyjskiej XX wieku (Kraków 1995), Wiara i naród. Twórczość Wtadimira Maksimowa (Kraków 2001), Andriej Amalrik - rosyjski dysydent (Kraków 2010), współautorka podręcznika akademickiego Rosjoznawstwo. Wprowadzenie do studiów nad Rosją (Kraków 2004). Prowadzi zajęcia dydaktyczne związane z szeroko pojmowaną kulturą i literaturą rosyjską XX i początków XXI w. 